\title{
均質電子線照射による高分子材料間の高速接着
}

\author{
佐 藤 浩 則 1 ,* 岩田圭 祐, ${ }^{2} \quad$ 利根川 $\quad$ 昭 $^{2} \quad$ 西 義 武1,2
}

1 東海大学大学院工学研究科金属材料工学専攻

2 東海大学大学院理工学研究科総合理工学専攻

J. Japan Inst. Metals, Vol. 72 , No. 7 (2008), pp. 526-531

(C) 2008 The Japan Institute of Metals

\section{Rapid Joining between Different Polymers Homogeneously Irradiated by Electron Beam}

\author{
Hironori Sato ${ }^{1, *}$, Keisuke Iwata ${ }^{2, *}$, Akira Tonegawa ${ }^{2}$ and Yoshitake Nishi ${ }^{1,2}$ \\ ${ }^{1}$ Department of Metallurgical Engineering, Graduate School of Engineering, Tokai University, Hiratsuka 259-1292 \\ ${ }^{2}$ Department of Science and Technology, Graduate School of Science and Engineering, Tokai University, Hiratsuka 259-1292
}

\begin{abstract}
Joining between Nylon-film and Silicone-rubber was successfully developed by using homogeneous EB irradiation. Effects of electron beam (EB) irradiation on joining strength of different polymers without adhesive materials were investigated. Although excess EB-irradiation more than $300 \mathrm{~kJ} \mathrm{~kg}^{-1}(\mathrm{kGy})$ apparently decreased the joining strength, the EB irradiation increased the joining strength of the joining sample between Nylon-film and Silicone-rubber. To discuss the influences of EB irradiation on the joining strength, electron spin resonance (ESR) signals related to dangling bonds were observed. Since EB irradiation generated dangling bonds on Nylon-film, dangling bonds probably supported the each other polymer at interface.
\end{abstract}

(Received November 21, 2007; Accepted April 9, 2008)

Keywords: electron beam, joining, polymer, Nylon film, Silicone rubber, dangling bond

\section{1. 緒言}

現在，生体用高分子材料や，それらの複合材料の接着には 接着剤による接着 1,2 や熱により溶着させる方法1)がある.し かし，熱溶着させる方法では，局部的な加熱による材料本来 の特性が変化してしまうことが懸念され1)，接着剤を用いた 接着においては，体内環境において悪影響を及ぼすことが懸 念される ${ }^{3)}$.もし，接着剤や熱溶着を用いずに短時間で接着 することが出来れば，これらの諸問題を解決できる画期的な 接着方法となる.

一方，低エネルギーの電子線 (EB) 照射処理は，無機透明 材料のぬれ性向上や防量効果などの報告がある ${ }^{4-6)}$.この, ぬれ性向上や防量効果は, EB 照射によるダングリングボン ドの形成により，表面エネルギーが向上するためとされてい る.シリコーンゴムではダングリングボンドの形成が確認さ れていないが，ナイロンフィルムには $\mathrm{EB}$ 照射により，ダン グリングボンドの形成が確認されている7). 異種高分子間の 接着では, 表面エネルギーが重要な因子になりえるという報 告もあり ${ }^{8)}$, 革新的な接着方法が提案できる可能性がある.

ところで, 生体用としてシリコーンゴムは人工弁 (ボール 弁)に用いられているが，膨張や強度面において破損の原因 となることが報告されている 度が高く, 耐摩耗性も優れているため, 生体用の中空系や人

\footnotetext{
* 東海大学大学院生 (Graduate Student, Tokai University)
}

工腱として用いられており10), シリコーンゴムと複合化す ることで, 様々な生体分野への応用が期待できる.

さらに, 滅菌処理として一般的な紫外線照射は処理に数時 間を要するのに対し, EB 照射は処理速度が秒単位で処理が 終了し, 医用・衛生材料技術としてだけでなく, 高速滅菌処 理として重要な技術である11,12). そのため, 生体内への応用 を考える上で, 従来の接着技術に比べ, 電子線照射により, 短時間で異種高分子を接着し, さらに滅菌作用が期待できる.

そこで, 本研究では, 金属材料, 半導体やセラミックスの 表面物性の評価手法を基盤とし, 従来の熱溶着や接着剤によ る手法以外の接着法として, ナイロンフィルムへの EB 照射 を行い, 異種高分子材料の接着について評価した.

\section{2. 実 験 方 法}

\section{1 電子線 $(\mathbf{E B})$ 照射}

本研究の試料はナイロンフィルム (ユニチカ製：エンブレ ム)とシリコーンゴム（篠田ゴム製：エルマ IS825)を用い た. ナイロンフィルムの試料形状は $10 \mathrm{~mm} \times 10 \mathrm{~mm} \times 0.025$ $\mathrm{mm}$, シリコーンゴムは $10 \mathrm{~mm} \times 10 \mathrm{~mm} \times 1 \mathrm{~mm}$ であった. 試料作製は, Fig. 1 に示すようにナイロンフィルムとシリ コーンゴムを接触させた状態で, 試料台に置き, その上から ナイロン保護フィルム (厚さ : $0.015 \mathrm{~mm}$ ) で圧縮応力 0.27 $\mathrm{MPa}$ を印加した状態で固定し, EB をナイロンフィルム側 から照射し, ナイロンフィルムとシリコーンゴムの異種高分 子同土を接着させた. EB 照射後, ナイロン保護フィルムを 


\section{EB irradiation}

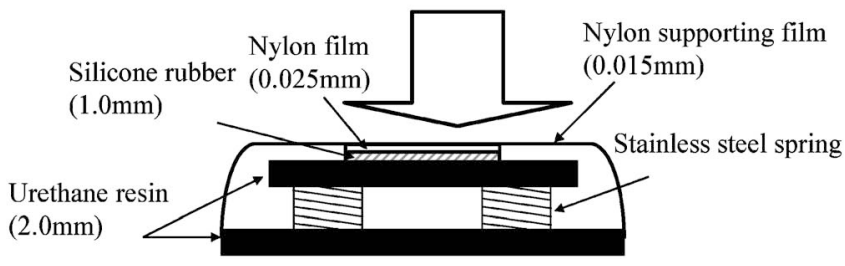

Fig. 1 Schematic drawing of joining process unit.

取り外した. この際, 試料と保護フィルム同士の接着は観察 されない.

$\mathrm{EB}$ 照射処理にはエレクトロカーテンプロセッサー(㧣岩 崎電気 Type CB175/15/180L)を用いた ${ }^{4-6)}$. EB 照射処理条 件は加速電圧 $170 \mathrm{kV}$, 照射電流 $2.0 \mathrm{~mA}$ とし, $\mathrm{EB}$ 照射処理 雾囲気は酸素濃度 $400 \mathrm{ppm}$ 以下の大気圧窒素雾囲気とし た。窒素の流量は $1.5 \mathrm{~L} \mathrm{~s}^{-1}$ である. EB 照射は試料を 150 $\mathrm{mm}$ 角の純アルミニウムの試料フォルダ上に置き, これをべ ルトコンベアに載せ, 照射を行い, コンベアースピードを $9.56 \mathrm{~m} \mathrm{~min}^{-1}$ で処理した. 温度の上昇を避けるため, 一回 の照射時間を 0.23 秒と一定とした. 照射直後に抢ける試料 の表面温度は $323 \mathrm{~K}$ 以下である。すなわち， EB 照射線量 は，照射回数を増加することにより照射線量を制御した。さ らに，試料の片面に電子線照射を行った。なお 1 回あたり の $\mathrm{EB}$ 照射線量は $43.2 \mathrm{~kJ} \mathrm{~kg}^{-1}(\mathrm{kGy})$ であった。照射線量の 校正は RCD 線量フィルム (FWT-60-00: FAR WEST TECHNOLOGY, カリフォルニア州) と吸光度測定用専用 リーダー(FWT-92D: FAR WEST TECHNOLOGY，カリフ オルニア州)からなるラジオクロミックフィルムナイロン線 量計を用いた． EB 照射による電子線の侵入深さ $D_{\mathrm{th}}$ の算出 式を式 (1)に示す13).

$$
D_{\text {th }}=66.7 V^{5 / 3} / \rho
$$

ここで $V$ は加速電圧 $(\mathrm{kV}), \rho$ は密度 $\left(\mathrm{kg} \mathrm{m}^{-3}\right)$ である. とこ ろで, 試料内の表面近傍に打的 $\mathrm{EB}$ 侵入深さを求める前に, $\mathrm{EB}$ 源における電圧 $\left(V_{0}\right)$ から試料表面に打都電圧 $\left(V_{\mathrm{s}}\right)$ まで $\mathrm{EB}$ が到達するまでのエネルギー損失 (電圧降下 : $\Delta V$ )を計 算することが必要である，そこで， EB 照射による電圧降下 は式(2)を用い算出を行った.

$$
\Delta V=t \cdot V_{0} / S
$$

ここで, $t$ は $\mathrm{Ti}$ の照射空の厚さおよび $\mathrm{N}_{2}$ ガス層の厚さ, $V_{0}$ は初期加速電圧, $S$ は質量厚さである。この時, $\mathrm{Ti}$ 製の照 射空および $\mathrm{N}_{2}$ ガス層それぞれの電圧降下を算出し，それを 全体の電圧降下とした. 以上の式より算出した, 電圧降下の 值を元に, 式 (3)を用いて試料表面に抢ける電位 $\left(V_{\mathrm{s}}\right)$ の算 出を行った。

$$
V_{\mathrm{s}}=V_{0}-\Delta V
$$

ここで， $V_{\mathrm{s}}$ は実効加速電圧， $V_{0}$ は初期加速電圧， $\Delta V$ は電 圧降下である。この式より算出した実効加速電圧を式 (1) へ代入することで各試料の侵入深さを算出した．本装置の $\mathrm{EB}$ 照射空はチタン製 $\left(\rho: 4540 \mathrm{~kg} \mathrm{~m}^{-3}\right)$ であり，厚さが 10 $\mu \mathrm{m}$ の薄板を使用している．また照射空から試料間は $30 \mathrm{~mm}$ であり, 大気圧の窒素ガス $\left(\rho: 1.13 \mathrm{~kg} \mathrm{~m}^{-3}\right)$ で満たされてい
Table 1 Calculated penetration depth by two methods.

\begin{tabular}{lcc}
\hline & Wakalopulos & Libby \\
\hline Nylon film $(\mu \mathrm{m})$ & 190 & 289 \\
\hline Silicone rubber $(\mu \mathrm{m})$ & 221 & 336
\end{tabular}

ることから, 電子の運動エネルギーはフィラメントより発生 された熱電子の発生時の $V_{0}=170 \mathrm{keV}$ から, 試料表面での $V_{\mathrm{s}}=128 \mathrm{keV}$ まで低下すると計算できる.

さらに, Libbyの提案による質量厚さの算出法を用いての 侵入深さは式 $(4)$ より算出した ${ }^{14)}$.

$$
l_{0}=1 / 150 \times E^{5 / 3}
$$

ここで, $l_{0}\left(\mathrm{mg} / \mathrm{cm}^{2}\right)$ は質量厚さ, $E(\mathrm{kV})$ は加速電圧であ る. 初期の加速電圧である $170 \mathrm{keV}$ の入射電子に対する mass thickness は約 $34.8 \mathrm{mg} / \mathrm{cm}^{2}$ と求まる. この值から Ti 膜および $\mathrm{N}_{2}$ ガス層の mass thickness $\left(1.78 \mathrm{mg} / \mathrm{cm}^{2}, 0.15\right.$ $\left.\mathrm{mg} / \mathrm{cm}^{2}\right)$ を差し引いて，その残りの值から中への侵入深さ を評価した。なお，今回用いたナイロンフィルムの $\rho$ は $1140 \mathrm{~kg} \mathrm{~m}^{-3}$ であり, シリコーンゴムの $\rho$ は $980 \mathrm{~kg} \mathrm{~m}^{-3}$ で ある。

以上 2 つ算出法による侵入深さの関係を Table 1 に示す.

なお 1 回あたりの電子線照射線量は $43.2 \mathrm{~kJ} \mathrm{~kg}^{-1}(0.426 \times$ $\left.10^{12} \mathrm{em}^{-2}=43.2 \mathrm{kGy}\right)$ である. ここで, 金属材料に対する照 射に拈いて一般的単位として用いられる電子数密度 $\left(\mathrm{em}^{-2}\right)$ は次式で示す ${ }^{15)}$.

$$
N g=D E / C g
$$

式中の $N g\left(\mathrm{em}^{-2}\right)$ は $1 \mathrm{~m}^{2}$ 当たり毎秒の電子の $1 \mathrm{~m}^{2}$ 当たり毎 秒の個数, $D E(\mathrm{~Sv} / \mathrm{s})$ が単位時間当たりの線量当量, $C g$ $\left((\mathrm{Sv} / \mathrm{s}) /\left(\mathrm{e} /\left(\mathrm{m}^{2} \mathrm{~s}\right)\right)\right.$ が線量当量率変換係数である.ここで, 本研究では $170 \mathrm{keV}$ の加速電圧を用いており, この時の $C g$ は $0.1649 \times 10^{-13}\left((\mathrm{~Sv} / \mathrm{s}) /\left(\mathrm{e} /\left(\mathrm{m}^{2} \mathrm{~s}\right)\right)\right.$ である.これらのこと から, 試料照射表面から接着界面までの距離は試料ナイロン とナイロン保護膜の厚さの和 $(40 \mu \mathrm{m})$ であるので, 界面は完 全に照射され，シリコーンゴムの厚さ $(1 \mathrm{~mm})$ の $20 \sim 30 \%$ 程 度照射される計算となる.

\section{2 接着強度}

本研究ではナイロンフィルムーシリコーンゴムの接着強度 を評価するために, Fig. 2 に示すように接着試料の両面を強 力接着剤(セメダイン㧣 : SUPER X)にてステンレス鋼棒 (泰豊トレーディングス：JIS 4318 相当 SUS304) と接着 し，引張試験片を作製し，接着強度の評価を行った。

強度評価にはインストロン型引張試験機を用い, 引張速度 $1 \mathrm{~mm} \min ^{-1}$ で行った. 得られた応力一歪曲線から破断応力 $\left(\sigma_{\mathrm{f}}\right)$ と破断歪 $\left(\varepsilon_{\mathrm{f}}\right)$, 変形抵抗率 $(\Delta \sigma / \Delta \varepsilon)$ を求めた.

\section{3 電子スピン共鳴 (ESR) 測定}

EB 照射処理によるナイロンフィルムおよびシリコーンゴ ムのダングリングボンドの発生, および変化を確認するため に, ESR 装置 (JES-FA200, 日本電子物)を用いてダングリ ングボンドの有無を測定した ${ }^{16,17)}$. ESR の測定条件は, 試 料を石英製の試料チューブに入れ，X-band(周波数：9.4〜 
$9.5 \mathrm{GHz}) 100 \mathrm{kHz}$ の変調磁場, 室温で測定した。マイクロ 波の出力は $1 \mathrm{~mW}$, 測定範囲は $316.9 \mathrm{mT}$ か $326.9 \mathrm{mT}$ まで とした。

\section{3. 結 果}

$3.1 \mathrm{~EB}$ 照射により接着させたナイロンフィルムーシリコー ンゴムの接着強度

Fig. 3 に接着させたナイロンフィルムーシリコーンゴムの 応力一歪曲線と照射線量の関係を示す。未処理であっても, 接着させたナイロンフィルムーシリコーンゴムの応力-歪曲線 が得られ，僅かな応力であるが，接着することを確認した.

Fig. 3 より，EB 照射を $129.6 \mathrm{kGy}$ した試料は，未照射試料 よりも接着強度が明らかに増加することを確認した．未照射 時の最大応力が $0.58 \mathrm{MPa}$ であるのに対し， $129.6 \mathrm{kGy}$ 照射 において $2.59 \mathrm{MPa}$ と末照射時よりも約 4.5 倍高い值を示し た。しかし， $129.6 \mathrm{kGy}$ 以上に過剰照射し，接着させたナイ ロンフィルムーシリコーンゴムの接着強度は， $129.6 \mathrm{kGy}$ 照 射した試料よりも接着強度が減少したが，未照射よりも高い 值を示すことが確認できる.

さらに, 応力一歪曲線から, 各変形歪に打矿抵抗応力で

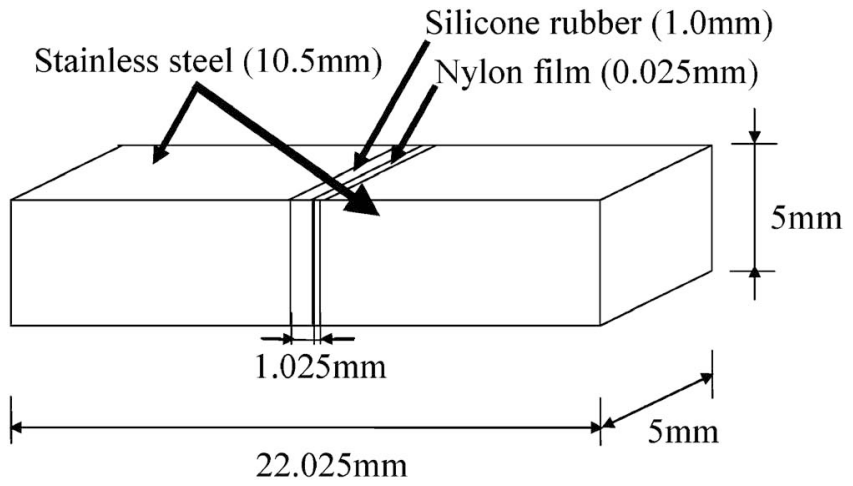

Fig. 2 Schematic drawing of Sample. (a) strain, $\varepsilon / \%$

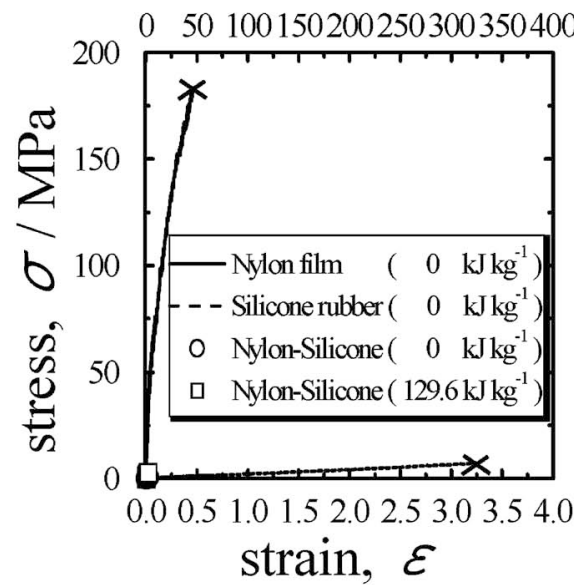

ある変形抵抗応力と変形歪量にともなう変形抵抗応力の割合 を示す変形抵抗率を求めた。本研究で応力-歪曲線の破断時 までの領域の傾きから求めた変形抵抗率は $\mathrm{EB}$ 照射により高 まることを確認している。

一方，未照射試料に比べ，EB 照射した試料の破断歪は一 般的に低下するが， $86.4 \mathrm{kGy}$ の照射した試料は破断歪が増 加することを確認している.

\section{$3.2 \mathrm{~EB}$ 照射による各試料の強度比較}

Fig. 4 にナイロンフィルムとシリコーンゴムおよび接着さ せたナイロンフィルムーシリコーンゴムの EB 照射前後の応 力-歪曲線 (Fig. 4(a)) と初期歪量における各試料の応力一歪 曲線 (Fig. 4(b)) の関係を示す. Fig. 4(b)より, 初期の歪量 において，接着させたナイロンフィルムーシリコーンゴムの

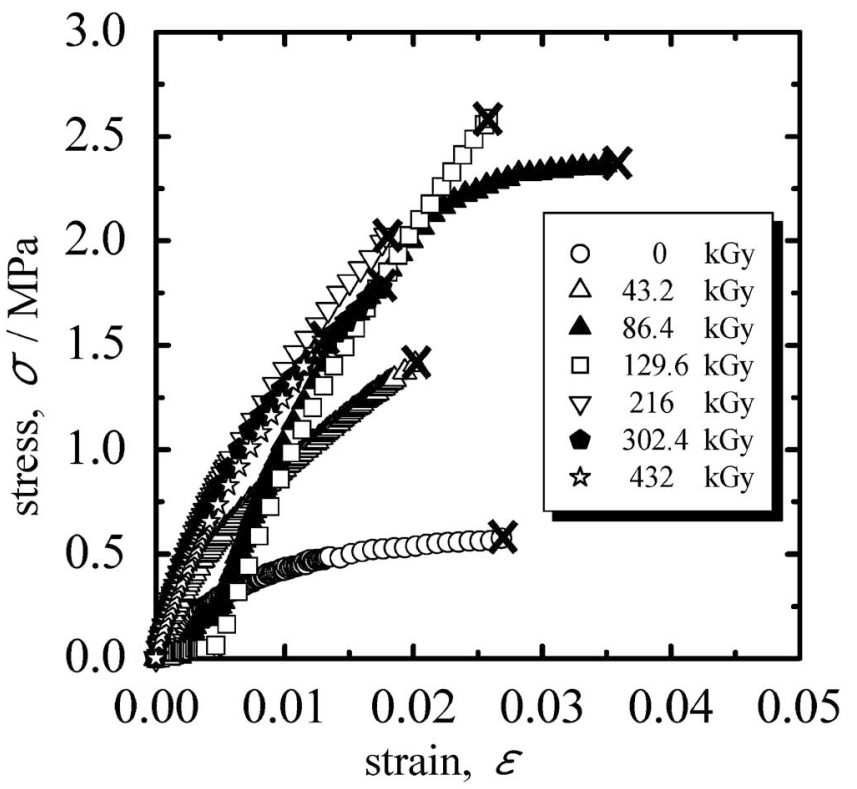

Fig. 3 Stress-strain curves of joining sample between Nylonfilm and Silicone-rubber at each dose of EB irradiation.

(b) strain, $\varepsilon / \%$

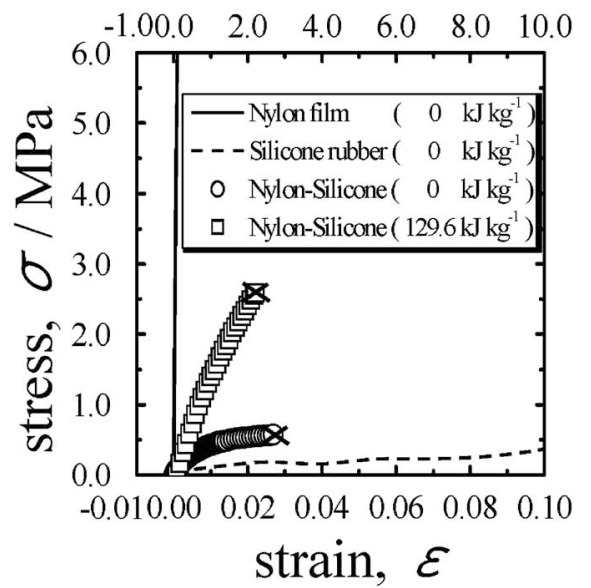

Fig. 4 Stress-strain curves of joining sample between Nylon-film and Silicone-rubber by EB irradiation, together with Nylon-film and Silicone-rubber, (a) and (b) are for long range (less than $200 \mathrm{MPa}$ of stress and $400 \%$ of strain) and short range (less than 6.0 $\mathrm{MPa}$ of stress and $10 \%$ of strain). 
(a) EB irradiation dose, $D / \mathrm{kGy}$

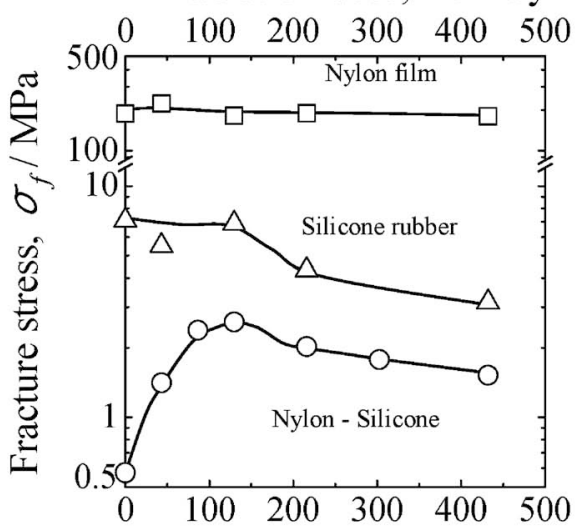

EB irradiation dose, $D / \mathrm{kJ} \mathrm{kg}^{-1}$ (b) EB irradiation dose, $D / \mathrm{kGy}$

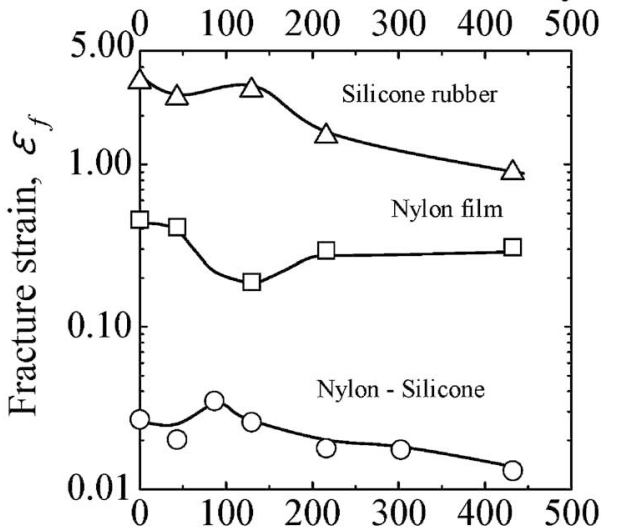

EB irradiation dose, $D / \mathrm{kJ} \mathrm{kg}^{-1}$

Fig. 5 Changes in fracture stress (a) and fracture strain (b) of joining sample between Nylon-film and Silicone-rubber, Nylon-film, and Silicone-rubber against each EB irradiation dose.

変形抵抗応力はナイロンフィルムよりは低いが，シリコーン ゴムの変形抵抗応力よりも高い值を示すことを確認している が，これは，EB 照射により接着強度が増大するだけでな く, シリコーンゴムが改質され変形抵抗が増大することも寄 与している.

EB 照射がナイロンフィルムおよびシリコーンゴムの引張 強度に及ぼす影響, さらには接着させたナイロンフィルムー シリコーンゴムの接着強度との関係を明確にするために,

Fig. 5 (a)にナイロンフィルム，シリコーンゴム拈よび接着 させたナイロンフィルムーシリコーンゴムの EB 照射線量と 破断応力の関係を示す. EB 照射により，ナイロンフィルム やシリコーンゴムにおいて破断応力は減少傾向を示すが，接 着させたナイロンフィルムーシリコーンゴムは $129.6 \mathrm{kGy}$ ま での $\mathrm{EB}$ 照射で接着強度を 4.5 倍も向上させることを確認し

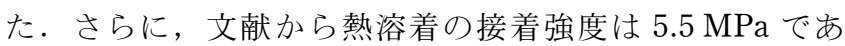
り18), 接着剂の接着強度は約 $2.5 \mathrm{MPa}$ であるため ${ }^{19)}$, 熱溶 着の最大值よりは劣るが，接着剂と同等の接着強度が得られ た。この結果は，高温が使えず，接着剤の使用が困難な場合 に, 電子線照射接着技術が効果的であることを示している.

Fig. 5(b)にナイロンフィルム，シリコーンゴム抢よび接 着させたナイロンフィルムーシリコーンゴムの照射線量と破 断歪の関係を示す. $129.6 \mathrm{kGy}$ の照射により，接着させたナ イロンフィルムーシリコーンゴムにおいて，照射前の破断歪 を保持したまま接着強度が向上した。この結果から，EB 照 射接着技術は接着強度が増大寸る処理であることを確認した。

\section{4. 考 察}

\subsection{EB 照射による接着強度と接着破断歪に及ぼす影響}

Fig. 5(a)において，ナイロンフィルムの破断応力は 129.6 $\mathrm{kJ} \mathrm{kg}^{-1}$ 以上の EB 照射において減少せず，シリコーンゴム の破断応力は減少した。この作用が影響し, ナイロンフィル ムーシリコーンゴムの $129.6 \mathrm{~kJ} \mathrm{~kg}^{-1}$ 以上の $\mathrm{EB}$ 照射によっ て，接着破断応力は減少した可能性が高い.

一方，Fig. 5(b)に拈いて，ナイロンフィルムの破断歪は，
$86.4 \mathrm{~kJ} \mathrm{~kg}^{-1}$ の EB 照射によって減少するが，シリコーンゴ ムの破断歪は減少しない。さらに，Fig. 5 (a)に見えるよう に, $86.4 \mathrm{~kJ} \mathrm{~kg}^{-1}$ の $\mathrm{EB}$ 照射により接着強度が増加する傾向 を示しており，この作用の効果により，接着破断歪も増加し た可能性が高い.

さらに，ナイロンフィルムの破断歪は $129.6 \mathrm{~kJ} \mathrm{~kg}^{-1}$ 以上の $\mathrm{EB}$ 照射によって減少し，シリコーンゴムの破断歪は $216 \mathrm{~kJ}$ $\mathrm{kg}^{-1}$ 以上の $\mathrm{EB}$ 照射によって減少した。これらの作用が相 互に影響し，接着破断歪は $216 \mathrm{~kJ} \mathrm{~kg}^{-1}$ 以上の $\mathrm{EB}$ 照射によ って減少傾向を示した可能性が高い.

以上の結果と考察から，86.4 129.6 kJ kg-1 の EB 照射 処理は, 短時間で接着強度が高く, 破壊丕も低下しないた め, 最適条件となる可能性が高い.

\subsection{EB 照射によるダングリングボンドの形成}

EB 照射によるダングリングボンドの存在を確認するため に，ESR によるシグナルを測定した．Fig. 6 に EB 照射前 後のナイロンフィルムおよびシリコーンゴムの ESR スペク トルの測定結果を示す．未照射の試料では両材料共に明確な ESR シグナルが観察されないことから，試料中にダングリ ングボンドがほとんど存在しない.

$129.6 \mathrm{kGy}$ 照射したナイロンフィルムでは ESR シグナル が見られ，試料中に $7.6 \times 10^{13} \mathrm{Spin} \mathrm{mm}^{-3}$ のダングリングボ ンドが存在することを確認し， $432 \mathrm{kGy}$ 照射時では, $2.4 \times$ $10^{14} \mathrm{Spin} \mathrm{mm}^{-3}$ のダングリングボンドを確認した。一方, $\mathrm{EB}$ 照射したシリコーンゴムでは明確な ESR シグナルが見 られなかった. しかし，Fig. 5 においてシリコーンゴムの強 度低下が見られており, 明確な ESR シグナルが確認できな かったが， $432 \mathrm{kGyEB}$ 照射した試料では僅かに ESR シグナ ルが観察され，各照射条件に損いて再現性が得られているこ とからも，ダングリングボンドが形成している可能性もある.

以上のことから，ナイロンフィルムだけでなくシリコーン ゴムにも，EB 照射することにより，界面分子間に適度な量 (7.6 ( \pm 0.6$\left.) \times 10^{13} \mathrm{Spin} \mathrm{mm}^{-3}\right)$ のダングリングボンドが形成 され，ナイロンフィルムとシリコーンゴムの活性化した表面 
分子とが結合し，接着強度が増加した可能性が高いと考えら れる.

一方， $432 \mathrm{kGy}$ 照射時のナイロンフィルムには $129.6 \mathrm{kGy}$ 照射時よりも多くのダングリングボンドが形成されており，

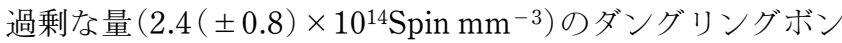
ドが形成されているが，原子(分子)間の切断が，余りに多く 存在することで，ナイロンフィルムの強度低下を引き起こ し, さらに，接着強度の低下を誘起した可能性もある.

同様に ESR シグナルの検出が困難なシリコーンゴムへの $432 \mathrm{kGy}$ の照射はダングリングボンドの僅かな存在を示すこ とから，ナイロンと同様な機構で強度劣化を引き起こしたと 考えられる。

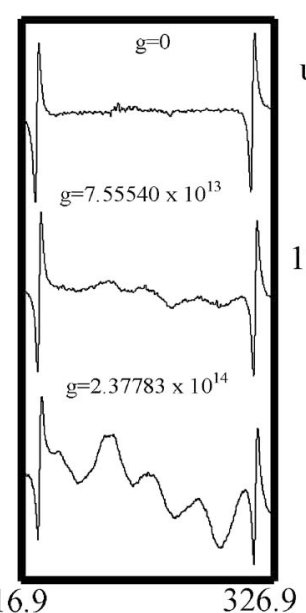

Magnetic Fields, $B$ / m T

(a) Nylon film

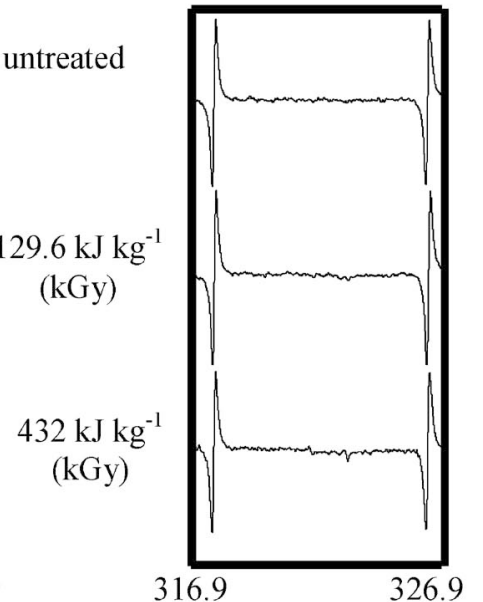

Magnetic Fields, $B$ / m T

(b) Silicone rubber
Fig. 6 ESR signals on Nylon-film (a) and Silicone-rubber (b) by EB irradiation.
$4.3 \mathrm{~EB}$ 照射による接着させたナイロンフィルムーシリコー ンゴムの変形抵抗率の変化

ナイロンフィルムとシリコーンゴムおよび接着させたナィ ロンフィルムーシリコーンゴムの各照射量の試料における変 形抵抗率の変形歪依存性を Fig. 7-(a)に示す. 変形抵抗率は 変形ひずみの増加に伴い低下することが確認出来る．接着さ せたナイロンフィルムーシリコーンゴムの変形抵抗率はナィ ロンフィルム，シリコーンゴムの変形抵抗率の間の值を示す ことが確認された。

さらに, Fig. 7-(a) から初期変形歪領域のみ取り出し，こ の初期変形抵抗率の照射量依存性を Fig. 7-(b)に示す. Fig. 7-(b) より，ナイロンフィルム，シリコーンゴムおよび，接 着させたナイロンフィルムーシリコーンゴムは照射量の増加 とともに変形抵抗率が高くなる傾向を示している.これは, EB 照射によって, Fig. 3 で示した接着強度の増加と同様の 傾向を示す。しかし， $432 \mathrm{kGy}$ 照射時に接着強度は 129.6 $\mathrm{kGy}$ 照射時よりも低い值を示すが，変形抵抗率はそれより も高い值を示している。これは，Fig. 7-(b)に見られるシリ コーンゴムの EB 改質効果により，主に説明できる．柔らか いシリコーンゴムはダングリングボンドが形成されても，分 子の移動が容易なため，短時間しか存在することができず， 過剰に存在しにくいため延性が低下せず，EB 照射により分 子間間隔がポテンシャルカーブの最適值に近づく方向に作用 する場合に，この説明が成立する。

\section{5. 結言}

本研究では, 高分子間(ナイロンフィルムーシリコーンゴ ム)の EB 照射による接着について検討を行うため，照射前 後におけるこれらの高分子間の接着強度の変化を測定した。 その結果， EB 照射後のナイロンフィルムーシリコーンゴム は，未照射よりも高い接着強度を示した。さらに，86.4〜 (a)

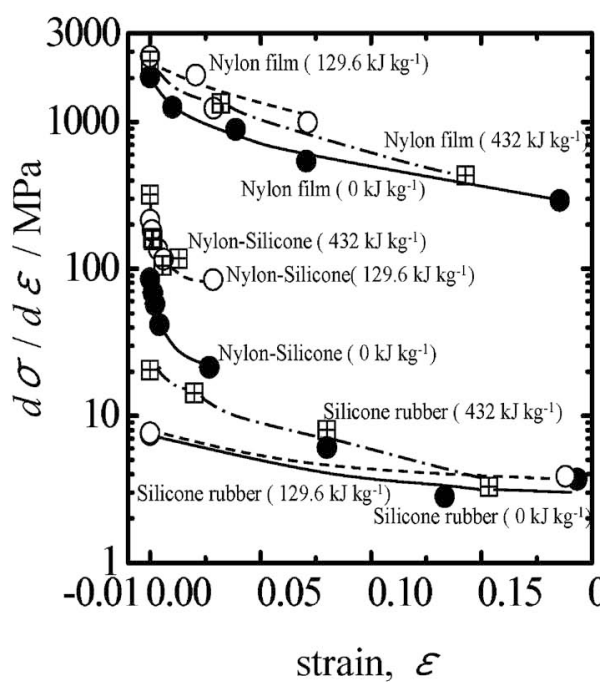

(b) EB irradiation dose, $D / \mathrm{kGy}$

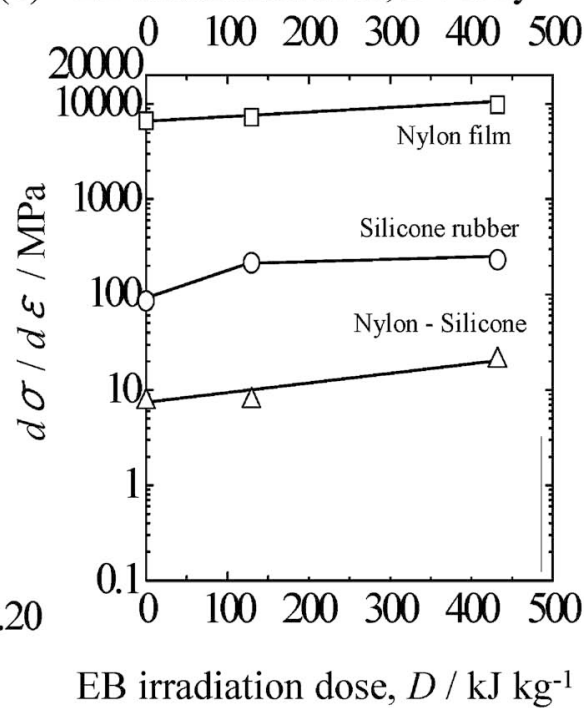

Fig. 7 Changes in deformation resistivity against strain at each EB irradiation dose (a) and changes in deformation resistivity against each EB irradiation dose (b) of joining sample between Nylon-film and Silicone-rubber, Nylon-film, and Silicone-rubber. 
$129.6 \mathrm{~kJ} \mathrm{~kg}^{-1}$ の $\mathrm{EB}$ 照射処理は, 短時間で接着強度が高 く, 破壊丕も低下しないため, 最適条件となる可能性が高い ことを確認した．接着させたナイロンフィルムーシリコーン ゴムは $129.6 \mathrm{kGy}$ までの $\mathrm{EB}$ 照射で接着強度を 4.5 倍も向上 することを確認した。この結果は, 熱溶着の接着強度よりは 劣るが，接着剤と同等の接着強度が得られることを示してい る.すなわち, 高温が使えず, 接着剤の使用が困難な場合に, EB 照射接着技術が効果的であることを確認した。

接着強度の増大は, $\mathrm{EB}$ 照射により, 界面分子間に適度な 量のダングリングボンドが形成され，ナイロンフィルムとシ リコーンゴムの表面分子とが結合し, 接着強度が増加した可 能性が高いためと考えられる.

一方，ナイロンフィルムに $432 \mathrm{kGy}$ 照射時には 129.6 $\mathrm{kGy}$ 照射時よりも多くのダングリングボンドが形成されて おり, 過剩な量のダングリングボンドが形成されたことによ って, ナイロンフィルムの強度低下があり, さらには接着強 度が低下した可能性がある. また，明確なシリコーンゴムの ESR シグナルは観察出来なかった．これはシリコーンゴム の分子運動の容易さから, もし, ダングリングボンドが形成 されても, 存在時間が微小であると仮定すると, 消滅し, ESR シグナルが観察されないことで説明できる。すなわ ち, シリコーンゴムに形成した微小時間存在するダングリン グボンドが接着に寄与している可能性もある.

\section{文献}

1) M. Kobayashi: Plastics. 41(1990) 84-89.

2) T. Nakayasu and Y. Oohashi: Technology on Adhesion \& Sealing. 46(2002) 451-456.

3) T. Hayashi: J. Japan Welding Society 39(1990) 141-146.

4) K. Oguri, K. Fujita, M. Takahashi, Y. Omori, A. Tonegawa, N. Honda, M. Ochi, K. Takayama and Y. Nishi: J. Mater. Res. 13 (1998) 3368-3371.

5) K. Oguri, N. Iwataka, A. Tonegawa, Y. Hirose, K. Takayama and Y. Nishi: J. Mater. Res. 16 (2001) 553-557.

6) K. Oguri and Y. Nishi: Mater. Trans. 45(2004) 1346-1349.

7) R. Suenaga, M. Kanda, N. Hironaka and Y. Nishi: J. Japan Inst. Metals. 72(2008) 35-38.

8) T. Shimaru: Technology on Adhesion \& Sealing. 3(1959) 121130.

9) M. M. McHenry, E. A. Smeloff, W. Y. Fong, G. E. Miller, Jr. and P. M. Ryan: J. Thorac. Cardiovasc. Surg. 59(1970) 413.

10) T. Hayashi and T. Masuda: J. Society Mate Sci. 39 (1990) 141146.

11) A. Kasashima, N. Iwataka, J. Kawano, N. Honda and Y. Nishi: J. Adv. Sci. 9(1997) 70-71.

12) S. Kinoshita: J. Illum. Engng. Inst. Jpn. 91 (2007) 210-215.

13) R. Christenhusz and L. Reimer: Z. Angew. Phys. 23 (1967) 396404.

14) W. F. Libby: Anal. Chem. 19 (1947) 2-6.

15) N. Tsuoulfanidis: Measurement and Detection of Radiation (in Japanese: Housyasen Keisoku no riron to ensyuu), (Gendai Kougakusya, Tokyo, 1983) pp. 543-552.

16) Y. Nishi, A. Mizutani, A. Kimura, T. Toriyama, K. Oguri and A. Tonegawa: J.Mater. Sci. 38(2007) 89-92.

17) N. Yamaguchi, K. Oguri, A. Tonegawa and Y. Nishi: J. Japan Inst. Met. 68 (2004) 198-201.

18) M. Matsutani: Plastics Gijutu Manual, (Rikougakusya, Tokyo, 1989) pp.7.6-7.7.

19) S. Takahashi: Zairyou Kagaku. 33(1996) 206-214. 